\title{
THE BURDEN OF UNANTICIPATED INFLATION: ANALYSIS OF AN OVERLAPPING-GENERATIONS MODEL WITH PROGRESSIVE INCOME TAXATION AND STAGGERED PRICES
}

\author{
BurkHard HeEr \\ Free University of Bolzano
}

\section{Alfred MAUßNER \\ University of Augsburg}

Inflation is often associated with a loss for the poor in the medium and long term. We study the short-run redistributive effects of unanticipated inflation in a dynamic optimizing sticky price model of the business cycle. Agents are heterogeneous with regard to their age and their productivity. We emphasize three channels of the effect of inflation on income distribution: (1) factor prices, (2) "bracket creep," and (3) sticky pensions. Unanticipated inflation that is caused by monetary expansion is found to reduce income inequality. In particular, an increase of the money growth rate by one standard deviation results in a 1\% drop of the Gini coefficient of disposable income if extra tax revenues are transferred lump-sum to the households.

Keywords: Unanticipated Inflation, Wealth Distribution, Income Distribution, Inequality, Progressive Income Taxation, Calvo Price Staggering

\section{INTRODUCTION}

The redistributive effects of inflation have been analyzed in numerous studies of the U.S. economy. Galli and van der Hoeven (2001) provide a survey of the empirical literature. In the majority of the studies, inflation is found to increase income inequality. Romer and Romer (1998), Bulir (2001), and Easterly and Fischer (2001) also point out in their empirical analysis that inflation hurts the very poor ${ }^{1}$ in high-inflation countries. However, the evidence is inconclusive for countries with low inflation rates.

We would like to thank Lawrence J. Christiano, Matthias Doepke, Martin Eichenbaum, Jonathan Heathcote, JoséVictor Ríos-Rull, Yaz Terajima, Eric Young, and two anonymous referees for their comments. All remaining errors are ours. Burkhard Heer kindly acknowledges support from the German Science Foundation (Deutsche Forschungsgemeinschaft DFG) during his stays at Georgetown University, the University of Pennsylvania, and Stanford University. Address correspondence to: Burkhard Heer, School of Economics and Management, Free University of Bolzano, Piazza Università 1, I-39100 Bolzano, Italy; e-mail: Burkhard.Heer@unibz.it. 
Using data from the Flow of Funds Account of the United States and the Survey of Consumer Finances, Doepke and Schneider (2006b) document the effects of inflation on holdings of nominal assets for U.S. households depending on age and net wealth and also its distribution between the household sector, the government, and foreigners. For this reason, they determine the amount and the maturity of both direct and indirect nominal positions, where the latter arise through equity holdings in businesses and investment intermediaries such as pension funds. They show that redistribution takes the form of "ends-against-the-middle," meaning that the middle class gains at the expense of the rich and poor. In a simple theoretical framework of a very stylized overlapping-generations (OLG) model, Doepke and Schneider (2006a) demonstrate that a zero-sum redistribution of wealth can have significant aggregate effects as winners and losers may show very different quantitative reactions to these changes. For example, a drop in wealth of a retired worker will not have any effect on his labor supply, whereas a compensating rise in the wealth of a working agent may reduce his labor supply, ceteris paribus. Doepke and Schneider (2006c) use a large-scale heterogeneous-agent model with (OLG) in order to study the quantitative aggregate and welfare effects of the wealth redistribution. They assume that unanticipated inflation causes a change in assets in the same way as identified in their previous empirical study [Doepke and Schneider (2006b)]. To replicate the empirical wealth distribution in their model, they allow households to hold both financial assets and housing and to leave bequests, the government to issue nominal debt, and firms to use both physical and intangible capital in production. As a consequence of an unanticipated inflation, the aggregate labor supply declines, whereas aggregate savings increase. In addition, aggregate output decreases, whereas average welfare rises.

Meh and Terajima (2008) apply the methods of Doepke and Schneider (2006b) to study the effects of unanticipated inflation on redistribution in Canada. The household distribution of nominal assets is similar in the United States and Canada. However, middle-aged middle-class households are large borrowers in the United States, whereas they are large savers in Canada. In addition, foreigners are net lenders in the United States, whereas they are net borrowers in Canada. In accordance with Doepke and Schneider (2006b), Meh and Terajima (2008) find that the redistribution of an unanticipated increase of inflation is large. In particular, the changes in wealth among the different age and household classes and the redistribution from the households to the government sector following an unexpected increase of $1 \%$ over five years amounts to several percentage points of GDP in Canada. Meh et al. (2008) show that the magnitude of the redistribution depends on monetary policy. For Canada, inflation targeting results in wealth changes that are about three times larger than those associated with price-level targeting.

To the best of our knowledge, all these empirical studies analyze the effects of inflation at low frequencies. Whereas most studies use the annual data set of Deininger and Squire (1996), Doepke and Schneider (2006b, 2006c) look at a hypothetical 10-year return of a high-inflation period that redistributes income from the lender to the borrower among the current U.S. households. However, 
we do not know of any empirical or dynamic general equilibrium (DGE) study that considers inflation and income inequality at business-cycle frequencies with quarterly or monthly data. Consequently, the cyclical redistributive effects of inflation are basically unknown.

This paper presents a DGE model that is able to study the impact of inflation on the distribution of both income and wealth over the business cycle. Therefore, it provides a first step to the analysis of the distributional effects of monetary policy. Our model is an extension of a standard Neo-Keynesian model. In order to model the short-run effects of monetary policy, we assume that prices are sticky and adjust as in Calvo (1983). Following an unexpected rise of the money growth rate, we observe unexpected inflation. Prices and markups adjust endogenously in our economy. In light of the contribution of Doepke and Schneider (2006b, 2006c), we also account for the fact that the effect of inflation on individual income and wealth depends on age and idiosyncratic productivity. Therefore, we consider an OLG model that is able to replicate the empirical distribution of income closely. We emphasize three channels of the effect of inflation on income inequality: (1) factor prices, (2) "bracket creep," and (3) sticky pensions.

(1) Following a monetary expansion, demand goes up and factor prices increase. As a consequence, we also observe unanticipated inflation. The increase in wages results in higher labor income among all workers, especially among the older and more productive workers.

(2) In addition, we model the so-called "bracket creep" effect. The tax brackets are only adjusted to actual inflation with a lag. Therefore, if unanticipated inflation increases, income-rich agents face higher marginal and average tax rates and inflation redistributes income to the poor.

(3) Pensions are also indexed to actual inflation with a lag. Therefore, unanticipated inflation reduces the income of retired workers.

In general, we find that unanticipated inflation that stems from a monetary expansion decreases the concentration of both market income (which equals the sum of wage, interest, and profit income) and disposable income (which equals total after-tax income, including transfers and pensions). As one of the main reasons, we identify the behavior of the individual labor supply in response to a wage increase. The rise in inflation and, therefore, in demand results in an increase of real wages. Highly productive and older workers increase their labor supply by a larger percentage; for example, the most productive 50-year-old worker increases his labor supply by $0.63 \%$, whereas that of the least productive 20 -yearold worker only rises by $0.23 \%$. The quantitative redistributive effect of inflation on disposable income, however, depends on the modeling of the government sector. If the government spends its extra revenues on public consumption, the Gini coefficient of disposable income only drops by $0.014 \%$. If, instead, extra revenues are transferred lump-sum to the households, the drop amounts to $1.05 \%$.

Our analysis is most closely related to the general equilibrium model of Cysne et al. (2005), who consider a shopping-time economy. In their model, consumers have different access to a shopping-time technology. In particular, poor agents 
cannot use interest-bearing nominal bonds to economize on transaction costs. Accordingly, rich agents are able to pay a smaller inflation tax than poor agents. Whereas Cysne et al. (2005), however, do not consider sticky prices and analyze only the steady state behavior of their economy, we calibrate our DGE model and consider the cyclical responses of income inequality to both a monetary shock and a technology shock. In addition, we also provide for a realistic modeling of the wealth distribution, which, of course, is important when we study the redistributive channel of inflation that works through its effect on the return of assets.

Our paper is also related to the recent work by Erosa and Ventura (2002) and Heer and Süssmuth (2007) on the effects of inflation on wealth inequality. Both studies consider only changes in the long-run inflation rate that are fully anticipated. They find that a rise in the anticipated long-run inflation rate results in an increase of the wealth inequality. Erosa and Ventura (2002) emphasize the effect of inflation on the composition of the consumption-good bundle. Higher inflation results in an increase of the consumption of the credit good at the expense of the consumption of the cash good, and richer agents have lower credit costs. Heer and Süssmuth (2007) model the observation that not all agents have access to the stock market and, therefore, poorer agents are less likely to hold assets whose real return is not reduced through higher inflation. In addition, they consider the so-called "Feldstein channel" according to which higher inflation reduces real after-tax interest income. All these studies, however, refrain from modeling the effects of unanticipated inflation.

The paper is organized as follows. In Section 2, we describe the OLG model. The model is calibrated in Section 3, where we also describe the algorithm for our computation in brief. In Section 4, we analyze the nonstochastic steady state behavior of the model with a focus on the income and wealth distribution. Section 5 presents the results for the effects of unanticipated inflation on the distribution of income and wealth. We distinguish the two cases where higher inflation is caused by either a monetary expansion or a negative technology shock. Both shocks imply the same pattern for the dynamics of inflation and disposable income. In Section 6, we study the business-cycle behavior of our stochastic OLG model and compare it with the corresponding representative-agent Ramsey model. In accordance with Ríos-Rull (1996), we find that the two models behave almost identically with regard to the aggregate variables. Section 7 concludes. A more detailed description of the stochastic OLG and the solution method is presented in a separate Technical Appendix. ${ }^{2}$

\section{THE MODEL}

The model is based on the stochastic OLG model with elastic labor supply and aggregate productivity risk, augmented by a government sector and the monetary authority. The model is an extension of Ríos-Rull (1996).

Four different sectors are depicted: households, firms, the government, and the monetary authority. Households maximize discounted lifetime utility with regard 
to their intertemporal consumption, capital and money demand, and labor supply. Firms in the production sector are competitive, whereas firms in the retail sector are monopolistically competitive and set prices in a staggered way as in Calvo (1983). The intermediate-good firms are using labor and capital as input into production. The government taxes income progressively and spends the revenues on government pensions, consumption, and transfers. Monetary policy is stochastic.

\subsection{Households}

Households live $T=240$ periods (corresponding to 60 years). The first $R-1=$ 160 (=40 years) periods, they are working; the last $T-(R-1)$ periods $(=20$ years), they are retired and receive pensions. The size of each generation $s$ is $\psi_{s}$. A member of generation $s$ survives with probability $\phi_{s}$ to age $s+1$, so that the mass of generation $s+1$ is given by

$$
\psi_{s+1}=\phi_{s} \psi_{s} .
$$

We normalize the total mass $\sum_{s=1}^{T} \psi_{s}$ to unity.

Agents are also heterogeneous with regard to their productivity level $\epsilon_{s, h}$. The productivity $\epsilon_{s, h}$ depends on the age $s$ and the productivity type $h \in\{1, \ldots, m\}$ at birth. Individual productivity is nonstochastic, and individuals will not change their productivity type $h$ over their lifetime. The share of type- $h$ agents in each generation is constant and denoted by $v_{h}$.

The $s$-year-old household with productivity type $h$ holds real money holdings $x_{t, s, h} / P_{t}$ and capital $k_{t, s, h}$ at period $t$. It maximizes expected lifetime utility in period $t$ with regard to consumption $c_{t, s, h}$, labor supply $n_{t, s, h}$, next-period money balances $x_{t+1, s+1, h}$, and real capital $k_{t+1, s+1, h}$, given its current assets $x_{t, s, h}$ and $k_{t, s, h}$ :

$$
\mathbf{E}_{t} \sum_{j=s}^{T} \beta^{j-s}\left(\prod_{i=s}^{j} \phi_{i}\right) u\left(c_{t_{j}, j, h}, \frac{x_{t_{j}, j, h}}{P_{t_{j}}}, 1-n_{t_{j}, j, h}\right), \quad t_{j}:=t+j-s,
$$

where $\beta$ is a discount factor and expectations $\mathbf{E}_{t}$ are conditioned on the information set of the household at time $t$. Instantaneous utility $u(\cdot)$ is assumed to be

$$
u\left(c, \frac{x}{P}, 1-n\right)=\frac{\left[c^{\gamma}\left(\frac{M}{P}\right)^{1-\gamma}\right]^{1-\sigma}-1}{1-\sigma}+\eta_{0} \frac{(1-n)^{1-\eta}}{1-\eta},
$$

where $\sigma>0$ denotes the coefficient of relative risk aversion. ${ }^{3}$ The agent is born without capital $k_{t, 1, h}=0, h \in\{1, \ldots, m\}$, but receives an initial cash endowment from the government $x_{t, 1, h}$ that is fixed in terms of the beginning of period price level $P_{t-1}$. 
The $s$-year-old working agent with productivity type $h$ faces the following nominal budget constraint in period $t$ :

$$
\begin{gathered}
P_{t}\left(k_{t+1, s+1, h}-(1-\delta) k_{t, s, h}\right)+\left(x_{t+1, s+1, h}-x_{t, s, h}\right)+P_{t} c_{t, s, h} \\
=P_{t} r_{t} k_{t, s, h}+P_{t} w_{t} \epsilon_{s, h} n_{t, s, h}+P_{t} t r_{t}+P_{t} \omega_{t, s, h}-P_{t} \tau\left(\frac{P_{t} y_{t, s, h}}{P_{t}^{I}}\right), \\
s=1, \ldots, T, \quad h=1 \ldots, m .
\end{gathered}
$$

The working agent receives income from effective labor $\epsilon_{s, h} n_{t, s, h}$ and capital $k_{t, s, h}$ as well as government transfers $t r_{t}$ and profits $\omega_{t, s, h}$, which is spent on consumption $c_{t, s, h}$, next-period capital $k_{t+1, s+1, h}$, and money $x_{t+1, s+1, h} \cdot w_{t}$ and $r_{t}$ denote the real wage rate per effective labor and the real interest rate, respectively. If the agent does not survive until period $t+1$, his or her wealth is collected by the government. ${ }^{4}$

We assume that aggregate profits $\Omega_{t}$ are distributed to households according to their shares in aggregate wealth, $\omega_{t, s, h}=\kappa_{s, h} \Omega_{t}$. Yet, because younger households may find it optimal to lend against future income, we restrict the distribution to households with positive assets. Furthermore, because our solution procedure (log-linearization at the balanced growth path) cannot deal with abrupt changes from negative to positive wealth, we use the shares that apply in the stationary equilibrium of our model. Thus, the shares of aggregate profits $\kappa_{s, h}$ received by a household of age $s$ and productivity type $h$ equal

$$
\begin{aligned}
\kappa_{s, h} & =\frac{\max \left\{0, k_{s, h}\right\}}{\bar{K}}, \\
\bar{K} & =\sum_{s=1}^{T} \sum_{h=1}^{m} \psi_{s} v_{h} \max \left\{0, k_{s, h}\right\},
\end{aligned}
$$

where $k_{s, h}$ are the capital holdings of the $s$-year-old household with productivity type $h$ in the nonstochastic steady state.

The household pays taxes on its nominal income $P_{t} y_{t, s, h}$ :

$$
P_{t} y_{t, s, h}=P_{t}\left(r_{t}-\delta\right) k_{t, s, h}+P_{t} w_{t} \epsilon_{s, h} n_{t, s, h}+P_{t} \omega_{t, s, h}
$$

In particular, the capital income-taxation scheme provides for a depreciation allowance.

The government collects taxes from nominal-income, but only adjusts the nominal-income tax schedule to the actual price level with a lag of $n \in\{0,1, \ldots\}$ quarters, where $n=0$ is perfect indexation. Therefore, nominal income is deflated by $P_{t}^{I}:=\pi^{n} P_{t-n}$, where $\pi$ denotes the nonstochastic inflation factor in the economy and the tax schedule is now given by

$$
\tau_{t, s, h}=\tau\left[\left(\prod_{i=0}^{n-1} \frac{\pi_{t-i}}{\pi}\right) y_{t, s, h}\right] .
$$


Notice that when we have high inflation, $\pi_{t}=P_{t} / P_{t-1}>\pi$, the real tax burden increases as the agent's real income moves into a higher tax bracket, the so-called "bracket creep" effect.

The nominal budget constraint of the retired worker is given by

$$
\begin{gathered}
P_{t}\left(k_{t+1, s+1, h}-(1-\delta) k_{t, s, h}\right)+\left(x_{t+1, s+1, h}-x_{t, s, h}\right)+P_{t} c_{t, s, h} \\
=P_{t} r_{t} k_{t, s, h}+P_{t}\left(\frac{P_{t} \operatorname{Pen}_{h}}{P_{t}^{I}}\right)+P_{t} t r_{t}+P_{t} \omega_{t, s, h}-P_{t} \tau_{t}\left(\frac{P_{t} y_{t, s, h}}{P_{t}^{I}}\right), \\
s=R, \ldots, T, \quad h=1, \ldots, m,
\end{gathered}
$$

with the capital stock and money balances at the end of life at age $s=T$ being equal to zero, $k_{t, T, h}=x_{t, T, h} \equiv 0$, for all productivity types $h \in\{1, \ldots, m\}$, because the household does not leave bequests. Furthermore, because retirement at age $R$ is mandatory, $n_{t, R, h}=n_{t, R+1, h}=\ldots=n_{t, T, h} \equiv 0$. Pensions $\operatorname{pen}_{h}$ depend on the productivity type $h$. Households with higher contributions to the pension system will receive higher pensions. ${ }^{5}$ Again, the government adjusts nominal pension payments in each period with a lag of $n$ periods. If inflation is higher than average, $\pi_{t}>\pi$, the real value of pensions declines. Accordingly, the real budget constraint of the $s$-year-old household with productivity type $h$ is given by

$$
\begin{aligned}
k_{t+1, s+1, h}+m_{t+1, s+1, h} & =\left\{\begin{array}{l}
\left(1+r_{t}-\delta\right) k_{t, s, h}+\frac{m_{t, s, h}}{\pi_{t}}+w_{t} \epsilon_{s, h} n_{t, s, h}+t r_{t}+\omega_{t, s, h} \\
-\tau_{t, s, h}-c_{t, s, h}, \quad \text { for } s=1, \ldots, R-1, \\
\left(1+r_{t}-\delta\right) k_{t, s, h}+\frac{m_{t, s, h}}{\pi_{t}}+\mathrm{Pen}_{t, s, h}+t r_{t}+\omega_{t, s, h} \\
-\tau_{t, s, h}-c_{t, s, h}, \quad \text { for } s=R, \ldots, T,
\end{array},\right.
\end{aligned}
$$

where we define $m_{t, s, h} \equiv x_{t, x, h} / P_{t-1}$.

The necessary conditions for the households with respect to consumption $c_{t, s, h}$, $s=1, \ldots, R-1$, next-period capital $k_{t+1, s+1, h}$, and next-period money $m_{t+1, s+1, h}$ at age $s=1, \ldots, T-1$ in period $t$ are as follows:

$$
\begin{aligned}
\lambda_{t, s, h} & =\gamma\left(c_{t, s, h}\right)^{\gamma(1-\sigma)-1}\left(\frac{m_{t, s, h}}{\pi_{t}}\right)^{(1-\gamma)(1-\sigma)}, \\
\lambda_{t, s, h} & =\beta \phi_{s+1} \mathbf{E}_{t} \lambda_{t+1, s+1, h} \\
\times & {\left[1+\left(1-\tau^{\prime}\left[\left(\prod_{i=0}^{n-1} \frac{\pi_{t+1-i}}{\pi}\right) y_{t+1, s+1, h}\right] \prod_{i=0}^{n-1} \frac{\pi_{t+1-i}}{\pi}\right)\left(r_{t+1}-\delta\right)\right], } \\
\lambda_{t, s, h} & =\beta \phi_{s+1} \mathbf{E}_{t} \lambda_{t+1, s+1, h}\left[\frac{1}{\pi_{t+1}}+\frac{(1-\gamma)}{\gamma} \frac{c_{t+1, s+1, h}}{m_{t+1, s+1, h}}\right] .
\end{aligned}
$$


The optimal labor supply of the productivity $h$-type workers at age $s=1, \ldots, R-$ 1 is determined by

$$
\eta_{0}\left(1-n_{t, s, h}\right)^{-\eta}=\lambda_{t, s, h}\left[1-\tau^{\prime}\left[\left(\prod_{i=0}^{n-1} \frac{\pi_{t-i}}{\pi}\right) y_{t, s, h}\right] \prod_{i=0}^{n-1} \frac{\pi_{t-i}}{\pi}\right] w_{t} \epsilon_{s, h} .
$$

\subsection{Monetary Authority}

The aggregate stock of nominal money balances held by households of ages $s=2$ through $T$ equals

$$
X_{t}:=\sum_{s=2}^{T} \sum_{h=1}^{m} \psi_{s} v_{h} x_{t, s, h}
$$

The monetary authority imperfectly monitors the growth rate $\left(\theta_{t}-1\right)$ of this aggregate and transfers the seignorage Seign ${ }_{t}$ to the government. Thus,

$$
\begin{gathered}
X_{t+1}=\theta_{t} X_{t}, \\
\operatorname{Seign}_{t}=\frac{X_{t+1}-X_{t}}{P_{t}}=\left(\theta_{t}-1\right) \frac{X_{t}}{P_{t}}=:\left(\theta_{t}-1\right) \frac{M_{t}}{\pi_{t}},
\end{gathered}
$$

where $M_{t}=\sum_{s=2}^{T} \sum_{h=1}^{m} \psi_{s} v_{h} m_{t, s, h}$. The percentage deviation of $\theta_{t}$ from its nonstochastic mean $\theta$ follows

$$
\hat{\theta}_{t}=\rho_{\theta} \hat{\theta}_{t-1}+\epsilon_{t}^{\theta}, \quad \epsilon_{t}^{\theta} \sim N\left(0, \sigma_{\theta}^{2}\right),
$$

where a circumflex over a variable denotes the percentage deviation of the variable from its steady state value and $\epsilon_{\theta t}$ is assumed to be i.i.d., $\epsilon_{\theta t} \sim N\left(0, \sigma_{\theta}^{2}\right)$.

Our definition of $M_{t}$, together with the assumptions regarding monetary policy, implies a dynamic equation in the aggregate real beginning-of period money stock:

$$
M_{t+1}=\frac{\theta_{t} M_{t}}{\pi_{t}}
$$

\subsection{Production}

A continuum of perfectly competitive firms produce the final output using differentiated intermediate goods distributed on $[0,1]$. These goods are manufactured by monopolistically competitive firms. Firms in the intermediate goods sector set prices according to Calvo (1983).

Final goods firms. The firms in the final goods sector produce the final good with a constant-returns to scale technology using the intermediate goods $Y_{t}(j)$, $j \in[0,1]$, as an input:

$$
Y_{t}=\left[\int_{0}^{1} Y_{t}(j)^{\frac{\epsilon-1}{\epsilon}} d j\right]^{\frac{\epsilon}{\epsilon-1}}
$$


Profit maximization implies the demand functions

$$
Y_{t}(j)=\left[\frac{P_{t}(j)}{P_{t}}\right]^{-\epsilon} Y_{t},
$$

with the zero-profit condition

$$
P_{t}=\left[\int_{0}^{1} P_{t}(j)^{1-\epsilon} d j\right]^{\frac{1}{1-\epsilon}}
$$

Intermediate goods firms. The intermediate good $j \in[0,1]$ is produced with capital $K_{t}(j)$ and effective labor $N_{t}(j)$ according to

$$
Y_{t}(j)=Z_{t} K_{t}(j)^{\alpha} N_{t}(j)^{1-\alpha},
$$

where $Z_{t}$ denotes a productivity shock, whose unconditional expectation equals $Z=1$. Off the balanced-growth path the $\log$ of $Z_{t}$ is governed by

$$
\ln Z_{t}=\rho_{Z} \ln Z_{t-1}+\epsilon_{t}^{Z},
$$

where $\epsilon_{t}^{Z}$ is normally distributed with mean zero and standard deviation $\sigma_{Z}$.

The firms choose $K_{t}(j)$ and $N_{t}(j)$ in order to maximize profits. In a symmetric equilibrium, profit maximization by the intermediate goods producers implies

$$
\begin{aligned}
r_{t} & =g_{t} \alpha Z_{t} K_{t}^{\alpha-1} N_{t}^{1-\alpha}, \\
w_{t} & =g_{t}(1-\alpha) Z_{t} K_{t}^{\alpha} N_{t}^{-\alpha},
\end{aligned}
$$

where $g_{t}$ denotes the inverse of the markup.

\subsection{Price Setting}

Prices are set according to the mechanism spelled out in Calvo (1983). In each period $(1-\varphi)$ of the firms in the intermediate goods sector are allowed to set their relative price $P_{t}(j) / P_{t}$ optimally. Depending on the assumptions about the information set and the adjustment rule for the remaining fraction of firms, we consider three different settings.

(1) A purely forward-looking Phillips curve arises if the price-setters choose their optimal relative price after the realization of the monetary shock and if the other firms (with index $N$ ) adjust their price according to

$$
P_{t}^{N}(j)=\pi P_{t-1}^{N}(j) .
$$

Profit maximization by symmetric firms leads to a condition that can be expressed as a dynamic equation for the aggregate inflation rate: ${ }^{6}$

$$
0=\hat{\pi}_{t}-\beta \mathbf{E}_{t} \hat{\pi}_{t+1}-\frac{(1-\varphi)(1-\beta \varphi)}{\varphi} \hat{g}_{t}
$$


(2) If we assume instead that nonoptimizing firms set their prices according to

$$
P_{t}^{N}(j)=\pi_{t-1} P_{t-1}^{N}(j),
$$

the log-linear Phillips curve becomes

$$
0=\hat{\pi}_{t}-\frac{1}{1+\beta} \hat{\pi}_{t-1}-\frac{\beta}{1+\beta} \mathbf{E}_{t} \hat{\pi}_{t+1}-\frac{(1-\varphi)(1-\beta \varphi)}{(1+\beta) \varphi} \hat{g}_{t} .
$$

(3) Finally, if the firms must set their optimal price before the realization of the money supply shock, equation (26) turns to

$$
0=\hat{\pi}_{t}-\frac{1}{1+\beta} \hat{\pi}_{t-1}-\frac{\beta}{1+\beta} \mathbf{E}_{t-1} \hat{\pi}_{t+1}-\frac{(1-\varphi)(1-\beta \varphi)}{(1+\beta) \varphi} \mathbf{E}_{t-1} \hat{g}_{t} .
$$

\subsection{Government}

Nominal government expenditures in period $t$ consist of pensions $\operatorname{Pen}_{t}$, the money endowment of the first generation, government consumption $G_{t}$, and lump-sum transfers $\operatorname{Tr}_{t}$ to households. Government expenditures are financed by an income tax $\operatorname{Tax}_{t}$, accidental bequests $\mathrm{Beq}_{t}$, and seignorage $\mathrm{Seign}_{t}$ :

$$
G_{t}+\operatorname{Tr}_{t}+\operatorname{Pen}_{t}+\sum_{h=1}^{m} v_{h} \psi_{1} \frac{m_{1, h}}{\pi_{t}}=\operatorname{Tax}_{t}+\operatorname{Beq}_{t}+\operatorname{Seign}_{t} .
$$

The income tax structure is chosen to match the current income tax structure in the United States most closely. ${ }^{7}$ Gouveia and Strauss (1994) have characterized the U.S. effective income tax function in the year 1989 with the following function:

$$
\tau(y)=a_{0}\left[y-\left(y^{-a_{1}}+a_{2}\right)^{-\frac{1}{a_{1}}}\right] .
$$

\subsection{Equilibrium Conditions}

(1) Aggregate and individual behavior are consistent; i.e., the sum of individual consumption, effective labor supply, capital, and money is equal to the aggregate level of consumption, effective labor supply, capital, and money, respectively:

$$
\begin{aligned}
C_{t} & =\sum_{h=1}^{m} \sum_{s=1}^{T} v_{h} \psi_{s} c_{t, s, h}, \\
N_{t} & =\sum_{h=1}^{m} \sum_{s=1}^{T} v_{h} \psi_{s} \epsilon_{s, h} n_{t, s, h}, \\
K_{t} & =\sum_{h=1}^{m} \sum_{s=1}^{T} v_{h} \psi_{s} k_{t, s, h},
\end{aligned}
$$

where the sum of the individual money balances is defined in (13).

(2) Households maximize lifetime utility (2).

(3) Firms maximize profits. 
(4) The goods market clears:

$$
Y_{t}=Z_{t} K_{t}^{\alpha} N_{t}^{1-\alpha}=C_{t}+G_{t}+K_{t+1}+(1-\delta) K_{t} .
$$

(5) Technology is governed by the AR(1)-process (22).

(6) Aggregate profits in the intermediate goods sector amount to

$$
\Omega_{t}=\left(1-g_{t}\right) Y_{t} .
$$

(7) The government budget (28) balances.

(8) Aggregate bequests amount to ${ }^{8}$

$$
\mathrm{Beq}_{t}=\sum_{s=1}^{T-1} \sum_{h=1}^{m}\left(1-\phi_{s}\right) \psi_{s} v_{h}\left(k_{t+1, s+1, h}+m_{t+1, s+1, h}\right) .
$$

(9) Given the tax function (29), aggregate taxes equal

$$
\operatorname{Tax}_{t}=\sum_{s=1}^{T} \sum_{h=1}^{m} \psi_{s} v_{h} \tau\left[\left(\prod_{i=0}^{n-1} \frac{\pi_{t-i}}{\pi}\right) y_{t, s, h}\right] .
$$

(10) Monetary growth (16) is stochastic and seignorage is transferred to the government.

The nonstochastic steady state and the log-linearization of the model at the nonstochastic steady state are described in more detail in the Technical Appendix to this paper.

\section{CALIBRATION AND COMPUTATION}

The OLG model is calibrated with regard to the characteristics of the U.S. postwar economy. We use standard values for the parameters of the model. Periods correspond to quarters. The first $R-1=160$ periods, agents are working; the remaining $T-(R-1)=80$ periods, they are retired. We distinguish two scenarios for the fiscal policy depending on the share $\xi \in\{0,1\}$ of the excess government revenues that are spent on public consumption (versus government transfers). In the first scenario, $\xi=1$, all extra revenues are spent on government consumption. We will refer to this case as our benchmark in the following. In the second scenario, $\xi=0$, government consumption is zero and all excess revenues are spent on lump-sum transfers to the households. In this section, we use a superscript $\xi \in\{0,1\}$ for the parameters $\left\{\gamma, \eta_{0}\right\}$ that are sensitive with regard to the fiscal policy.

\subsection{Preferences}

$\beta$ is set equal to 0.9975 , implying an annual capital-output ratio of about 2.0, which is almost independent of our choice of $\xi \in\{0,1\}$. For this choice, the nonstochastic steady state annual real rate of return before taxes amounts to $7.4 \%$. The relative risk-aversion coefficient $\sigma$ is set equal to 2.0. We choose $\eta=7.0$, which implies a conservative value of 0.3 for the Frisch labor-supply elasticity. ${ }^{9}$ $\eta_{0}^{0}=0.19\left(\eta_{0}^{1}=0.60\right)$ is set so that the average labor supply in the economy is approximately equal to $1 / 3$ in the two scenarios $\xi \in\{0,1\} . \gamma$ is chosen so that 
TABLE 1. Parameterization of the OLG model

\begin{tabular}{lllll}
\hline Demographics & $T=160$ & $T^{R}=80$ & & \\
Preferences & $\beta=0.9975$ & $\sigma=2.0$ & $\gamma^{0}=0.9775$ & $\gamma^{1}=0.9740$ \\
& $\eta_{0}^{0}=0.19$ & $\eta_{0}^{1}=0.60$ & $\eta=7.0$ & \\
Productivity types & $m=3$ & $\sigma_{z}^{2}=3.60$ & & \\
Production & $\alpha=0.36$ & $\delta=0.019$ & $\rho^{Z}=0.95$ & $\sigma^{Z}=0.007$ \\
Market structure & $\epsilon=6.0$ & $\varphi=0.25$ & & \\
Money supply & $\pi=1.013$ & $\rho_{\theta}=0.49$ & $\sigma_{\theta}=0.0089$ & \\
Government & $\zeta=0.5$ & $a_{0}=0.258$ & $a_{1}=0.768$ & $\frac{\tau(Y-\delta K)}{Y-\delta K}=0.104$ \\
\hline
\end{tabular}

the (annualized) average velocity of money $P Y / M$ is equal to the velocity of M1 during 1960-2002, $P Y / M=6.0$. This requires $\gamma^{1}=0.9740\left(\gamma^{0}=0.9775\right)$ in the scenario $\xi=1(\xi=0)$. Table 1 summarizes our choice of parameters.

\subsection{Individual Productivity}

The idiosyncratic productivity level is given by $\epsilon_{s, h}=e^{\bar{y}_{s}+z_{h}}$, where $\bar{y}_{s}$ is the mean lognormal income of the $s$-year-old and $z_{h}$ is the idiosyncratic component. The mean efficiency index $\bar{y}_{s}$ of the $s$-year-old is taken from Hansen (1993) and is interpolated to in-between quarters. As a consequence, the model replicates the cross-section age distribution of earnings of the U.S. economy. The productivity age profile is hump-shaped and earnings peak at age 50, corresponding to model period 121 (not displayed). With regard to the idiosyncratic component $z_{h}$, we follow Huggett (1996) and choose a log-normal distribution of earnings for the 20-year-old with a variance equal to $\sigma_{z}^{2}=3.60$. By this choice, the Gini coefficient of market income is equal to 0.55 and matches the empirical value estimated by Budría-Rodriguez et al. (2002) exactly. The productivity state $z_{h}$ is equally spaced and ranges from $-\sigma_{z}$ to $\sigma_{z}$. We discretize the state space using $m=3$ values and normalize $e^{z_{h}}$ so that $\sum_{h=1}^{m} v_{h} e^{z_{h}}=1 .^{10}$

\subsection{Government}

Pensions depend only on productivity type $h$. Following İmrohoroğlu et al. (1995), we choose a replacement ratio of pensions relative to average net wage earnings $\zeta$ equal to $50 \%, \zeta=\operatorname{Pen}_{h} /(1-\bar{\tau}) w \bar{n}_{h} . \bar{\tau}$ is the income tax rate on the average income in the nonstochastic steady state of the model, and

$$
\bar{n}_{h}=\sum_{s=1}^{R-1} \frac{\psi_{s}}{\sum_{j=1}^{R-1} \psi_{j}} \epsilon_{s, h} n_{s, h}
$$

is the average effective labor supply of productivity type $h$ over his or her working life, also computed from the labor supply in the nonstochastic equilibrium. 
Gouveia and Stauss (1994) characterize the U.S. effective income tax in the year 1989 with the function (29) and estimate its parameters as $a_{0}=0.258, a_{1}=0.786$, and $a_{2}=0.031$. We need to adjust this function to our model, because we assume quarterly tax payments and because the units of income $y$ in our model differ from those in the United States. We assume that the average tax rate on annual income equals the average tax rate on quarterly income, and that the average tax rate in our model equals the average tax rate on the average U.S. income in 1989, $y_{\mathrm{US}}=36,173$ [taken from Table A.1 of Gouveia and Strauss (1994)]:

$$
\frac{a_{0}\left(0.25 y_{\mathrm{US}}\right)-a_{0}\left[\left(0.25 y_{\mathrm{US}}\right)^{-a_{1}}+a_{2}\right]^{\frac{-1}{a_{1}}}}{\left(0.25 y_{\mathrm{US}}\right)}=\frac{a_{0} y-a_{0}\left(y^{-a_{1}}+\tilde{a}_{2}\right)^{\frac{-1}{a_{1}}}}{y} \text {. }
$$

Solving this equation for $\tilde{a}_{2}$ yields our adjusted tax schedule:

$$
\begin{aligned}
\tau(y) & =a_{0} y-a_{0}\left(y^{-a_{1}}+\tilde{a}_{2}\right)^{\frac{-1}{a_{1}}}, \\
\tilde{a}_{2} & =a_{2}\left(4 y_{u s} / y\right)^{a_{1}} .
\end{aligned}
$$

Note that the average income $y$ in our model itself depends on the tax schedule. Therefore, we must adjust $\tilde{a}_{2}$ in each step of our iterative computation of the stationary equilibrium (as described below) until convergence is achieved.

As an alternative taxation scenario, we consider the case of a flat income tax rate. In this case, we use the tax rate $\tau=10.4 \%$, which implies the same tax burden for the average income as in the case of progressive taxation. In the nonstochastic steady state of our model, the average income amounts to $Y-\delta K$ (see the Technical Appendix for a detailed description of the nonstochastic steady state).

\subsection{Monetary Authority}

In accordance with Cooley and Hansen (1995), the quarterly inflation factor is set equal to $\pi=1.013$. Money growth follows an AR(1)-process. For the postwar U.S. economy, Cooley and Hansen estimate $\rho_{\theta}=0.49$ and $\sigma_{\theta}^{2}=0.0089$. The initial endowments of money, $m_{1, h}$, for the different productivity types $h=1, \ldots, m$ are chosen to equal those of the one-quarter-older individuals of the same productivity type.

\subsection{Production}

The production elasticity of capital, $\alpha=0.36$, and the quarterly depreciation rate $\delta=0.019$ are taken from Prescott (1986) and Cooley and Hansen (1995), respectively. The value for the depreciation rate implies an annual investmentcapital ratio equal to 0.076 . In our analysis, we consider three different scenarios for the degree of price flexibility, using fractions $\varphi$ of producers, that do not adjust their prices in any quarter from the set $\{0,0.25,0.75\}$. The value of $\varphi=0$ represents the case of perfect price flexibility. $\varphi=0.25$ implies that prices change 
about every four months. This is in line with evidence provided by Bils and Klenow (2004) and Klenow and Kryvstov (2008). The more usual value of $\varphi=0.75$ is used in many studies that either exclude capital or introduce considerable costs of capital stock adjustment. With flexible capital, as in our model, this value produces so much price stickiness that output fluctuations are implausibly high. Therefore, and if not mentioned otherwise, the results presented below refer to $\varphi=0.25$.

Following empirical evidence presented by Basu and Fernard (1997), we set the average markup at the amount $1 / g=1.2$, implying a constant elasticity of substitution between any two intermediate goods equal to $\epsilon=6.0$.

The log of the aggregate technology shock follows an AR(1) process (22) with autoregressive parameter $\rho^{Z}=0.95$ and standard deviation $\sigma^{Z}=0.007$, as in Cooley and Prescott (1995).

\subsection{Computation}

In order to compute business cycle dynamics of the model, we first need to compute the nonstochastic steady state of the model. Second, we log-linearize the model around the nonstochastic steady state.

The nonstochastic steady state is computed by solving the respective system of nonlinear equations consisting of the first-order conditions of the generation born at time $t$, the government's budget constraint, the firms' first-order conditions, and the aggregate consistency conditions. In the case of $m=3$, this is a system of 2,634 variables. We employ a nonlinear equation solver that takes care of the admissible bounds within which the solution must lie. To obtain reasonable initial values, we started with a simplified version of our model without money and endogenous labor supply, where it is easy to solve for the optimal time profile of the capital stock. We expanded this model in several steps to the model presented above. The Technical Appendix provides additional details on the various models.

Thereafter, we log-linearize the model around the nonstochastic steady state and solve the ensuing linear rational-expectations model as explained in the Technical Appendix.

\section{ASSET AND INCOME DISTRIBUTION IN THE NONSTOCHASTIC STEADY STATE}

We present our results in the following three sections. Before we describe the redistributive effects of unanticipated inflation and the business-cycle properties in the next two sections, we first present the behavior of the variables in the nonstochastic steady state in this section. We pay particular attention to the distribution of the assets and income.

In the nonstochastic steady state, inflation and the technology level are constant. Figure 1 displays the consumption, savings, and labor supply profiles for ages 20 through 80 in our benchmark economy with government consumption. The $x$ axis displays age in lifetime years. The capital-age profile is hump-shaped, as 
Real money balances

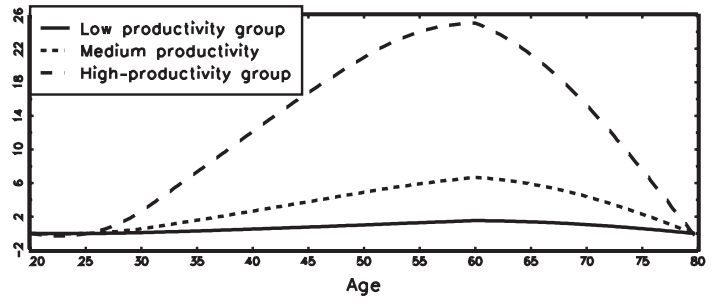

Disposable income

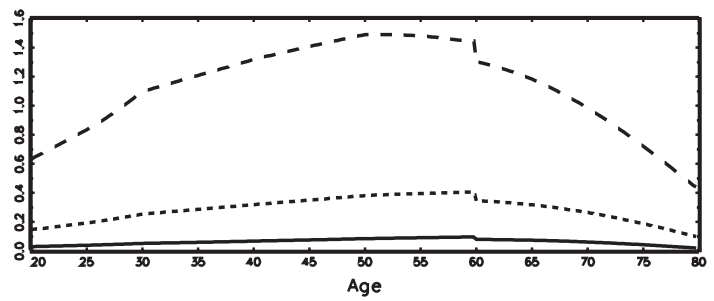

Hours

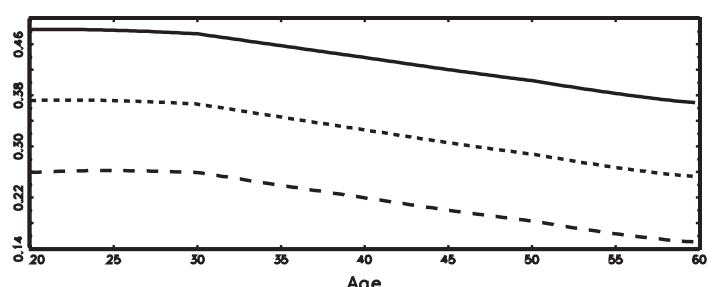

Consumption

Individual productivity
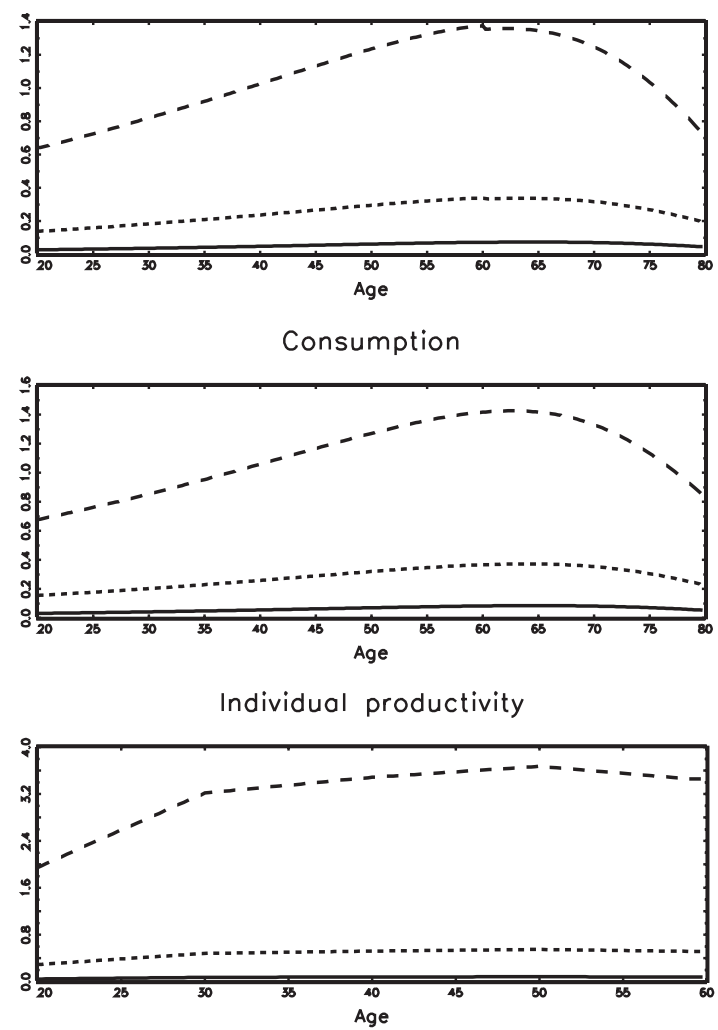

FIGURE 1. Stationary equilibrium, budget surplus spent on government consumption. 
displayed in the upper left graph in Figure 1. Notice that due to the hump-shaped productivity-age profile (shown in the lower right panel), medium- and highproductivity households dissave during the first three and six years, respectively. Only at real lifetime ages 23 and 26 do household start to build up positive savings. Agents with higher productivity attain higher levels of capital, money balances, and consumption. In addition, consumption and, therefore, money balances are decreasing during old age because the survival probabilities decline and utility is discounted at a higher rate.

Notice that the household behavior changes as households enter retirement and real money balances display a small drop. This kind of behavior is absent from most standard OLG models. The reason is the presence of progressive income taxation in our model. In the nonstochastic long-run equilibrium, the first-order conditions (10) and (11) can be condensed to

$$
\frac{m_{s+1, h}}{\theta}=\left\{\theta-1+\theta\left[1-\tau^{\prime}\left(y_{s+1, h}\right)(r-\delta)\right]\right\}^{-1}\left[\frac{1-\gamma}{\gamma}\right] c_{s+1, h}
$$

Because the marginal tax rate $\tau^{\prime}(\cdot)$ depends on income, the strict proportionality between consumption and the stock of real money balances observed in models with a constant tax rate breaks down. In particular, because the marginal tax rate drops markedly when the household retires, it readjusts its portfolio, giving rise to the sudden drop in his money stock.

As can be seen from the lower left graph of Figure 1, labor supply is almost constant during the first 10 years, during which individual productivity is characterized by a steep increase (consider the broken lines in the lower left and right panels for the high-productivity workers). Around age 30, labor supply starts to decline significantly and is close to half its initial value at the age of retirement for the high-productivity agents (the lower labor supply curve in the bottom left panel). The decline in the labor supply reflects the increasing wealth effect as agents build up savings. Also note the clear ranking in the labor supply-age profiles, with lowproductivity workers on the top and high-productivity workers at the bottom. ${ }^{11}$

In our model, income and wealth are distributed unequally. The inequality of the income distribution is in good accordance with that observed empirically. As pointed out in the previous section, the standard deviation of log productivity has been calibrated so that the Gini coefficient of market income is equal to 0.55 . Empirically, wealth is much more concentrated than income. In the 1998 SCF sample, Budría Rodriguez et al. (2002) find a Gini coefficient of wealth equal to 0.803 for the U.S. economy. In our model, the Gini coefficient of wealth only amounts to 0.65. Although our model is able to replicate the wealth distribution in the four lowest quintiles, it does a poor job in replicating the wealth concentration of the top percentile. ${ }^{12}$ To replicate the wealth distribution of the richest $1 \%$, one has to introduce entrepreneurship, as in Quadrini (2000), or preference heterogeneity, as in Krusell and Smith (1998). Finally, the correlation of market income (disposable 
income) and wealth amounts to $0.79(0.85)$ in our model, as compared to the empirical value of 0.60 reported by Budría Rodríguez et al. (2002).

\section{REDISTRIBUTIVE EFFECTS OF UNANTICIPATED INFLATION}

In this section, we describe the dynamics of the distribution following a monetary shock and a technology shock.

\subsection{Redistributive Effects of Monetary Policy}

An expansionary monetary shock increases demand, either directly, because the government spends the seignorage on consumption, or indirectly, via transfers to the households. As prices are sticky and firms are monopolistic competitors in the intermediate goods sector, output and employment increase. The impulse response functions of aggregate variables to a monetary growth shock $\epsilon_{\theta, 2}=\sigma_{\theta}$ in period 2 (and zero thereafter) are presented in Figure 2 for the case where pensions and taxes are indexed for one year $(n=4)$ and where the excess of government revenues over pensions are spent on goods. Moreover, prices are moderately sticky $(\varphi=0.25)$ and are set according to the Phillips curve (26), which also contains a backward-looking component. We will refer to this case as our benchmark model in the following.

In the first row of Figure 2, the percentage deviations of the variables money growth rate $\theta_{t}$, output $Y_{t}$, consumption $C_{t}$, and investment $I_{t}$ are graphed. In the second row, we illustrate the percentage deviations of government spending $G_{t}$, hours, real money $M_{t}$, and the inflation factor $\pi_{t}$. In the third row, we have the behavior of marginal costs $g_{t}$ (the inverse of the markup), profits $\Omega_{t}$, the user costs of capital $r_{t}$, and the wage rate $w_{t}$. The dotted lines display the impulse responses from the representative-agent version of our model. This model is outlined in the Technical Appendix and has been calibrated so that the capital-output ratio, the income velocity of money, and average working hours in the nonstochastic steady state of the model equal the respective quantities in the OLG model.

The percentage changes of output and hours are moderate and amount to 0.30 and $0.34 \%$, respectively, whereas the drop in investment by $4.2 \%$ is more pronounced. This reflects the crowding out of private expenditures by the huge increase of government consumption of about $7 \%$ and the agent's desire to smooth consumption. Inflation, the user costs of capital, and wages all increase, whereas profits decrease. Our OLG model inherits the behavior of almost all of its variables from the representative-agent model. The most noticeable differences concern consumption and investment. In the OLG model, consumption decreases by 0.09 percent in the period of the shock, which is about 50\% larger than the response in the representative-agent model. Furthermore, in the OLG model, investment drops about $5.4 \%$ below its stationary value in the second period after the shock, which is about 0.8 percentage points larger than the response in the representative agent model. Also, notice that many variables strongly undershoot in the second 

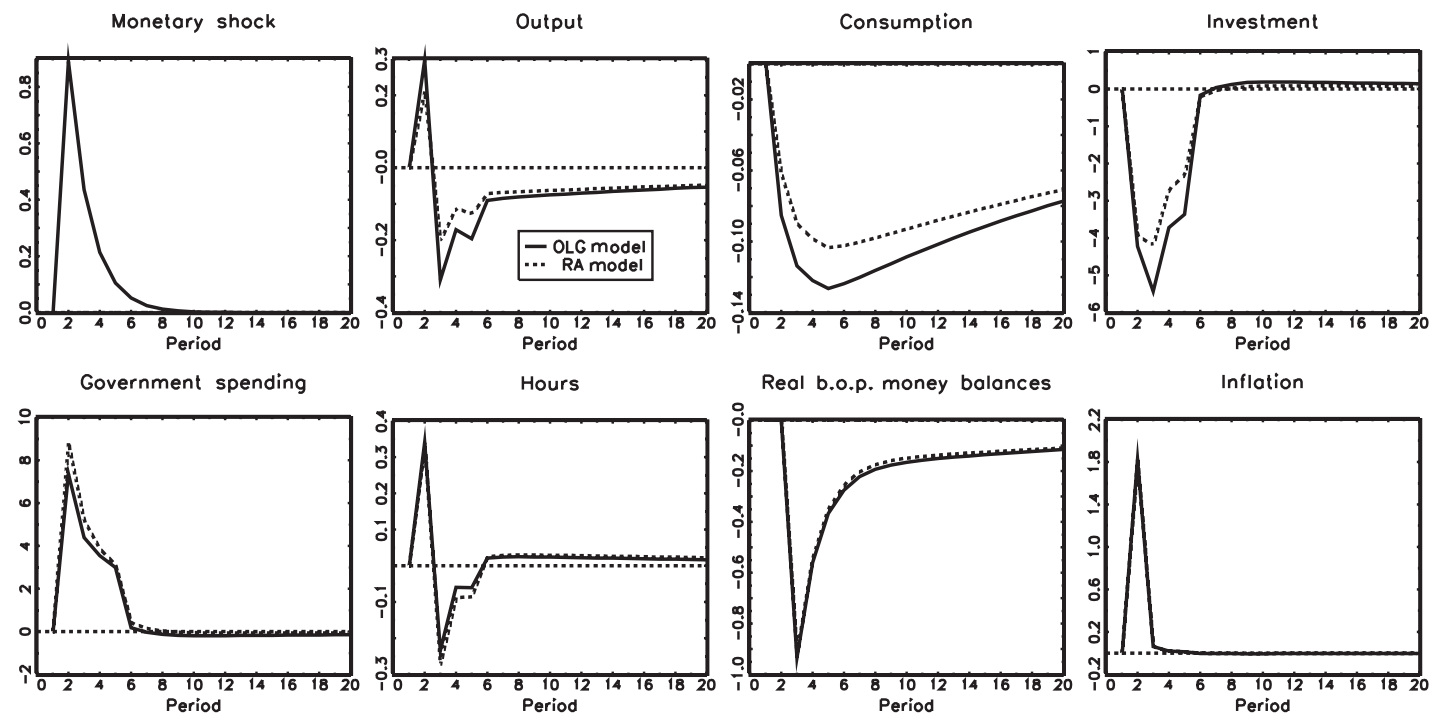

Marginal costs
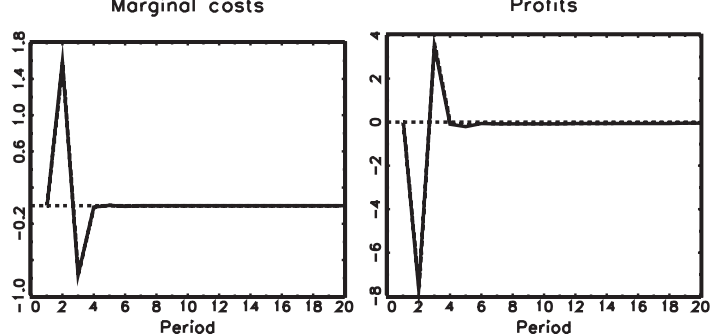

User costs of copitol

Real woge rate
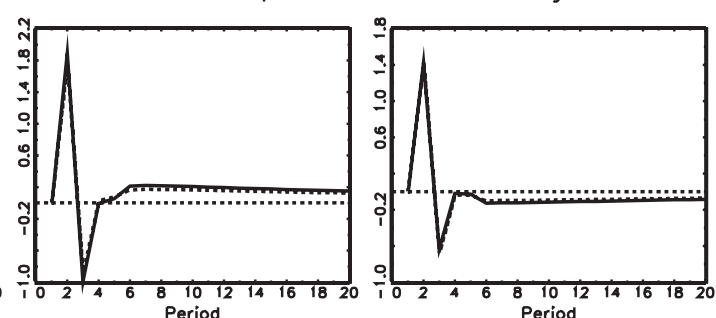

FIGURE 2. Impulse response to a monetary shock, $n=4, \operatorname{Tr}_{t}=0$. 
Gini ratio of market income

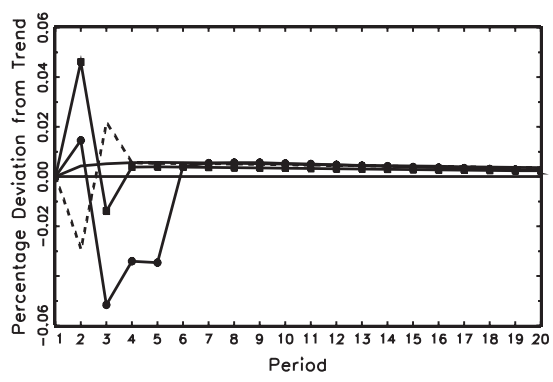

Gini ratio of wealth

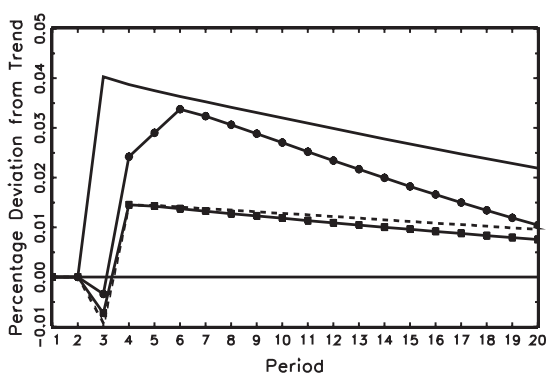

Gini ratio of disposable income

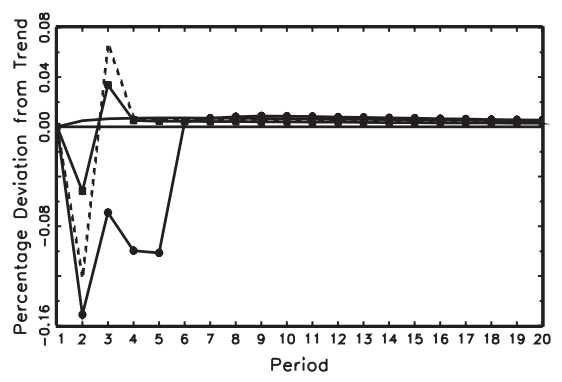

- Proportional tax, without frictions

-. Proportional tax, sticky prices, no indexation

- Progressive tox, sticky prices, no indexation

- - Progressive tox with all frictions

FIGURE 3. Distributional effects of a monetary shock, $\operatorname{Tr}_{t}=0$.

period after the shock. This is a consequence of the lagged adjustment of inflation. It disappears in the model with the Phillips curve (25) and a more moderate degree of indexation $(n=1)$.

In order to understand the contribution of the various transmission channels of monetary policy to the distribution, we have computed the model for various cases, starting from the OLG model with flexible prices, proportional taxes, and no indexation of pensions and taxes and adding one new element each time: sticky prices, tax progression, and indexation of taxes and pensions.

In the upper left panel of Figure 3, we see that the effect of a monetary shock on market income in an economy with flexible prices and proportional taxes (the solid line) is basically zero: a one-standard-deviation increase of the money growth factor, $\sigma_{\theta}=0.89$, increases the Gini coefficient of market income by $0.004 \%$ and the Gini coefficient of disposable income by $0.005 \%$. Even though these changes are extremely small, it helps to to trace the different sources of this slightly more unequal distribution in order to understand the working of the full model.

First, the responsiveness of the individual labor supply to wage increases depends on age and the productivity type [see the lower right panel of Figure 4, where the wage elasticity $\left(1-n_{s, h}\right) / \eta n_{s, h}$ is plotted]. The most productive old workers - who are also the richest in the population-are very sensitive to wage changes, and thus increase their labor supply relatively more than young and lowproductivity workers. Second, in the case of flexible prices, the shock increases 
Aggregate response of hours

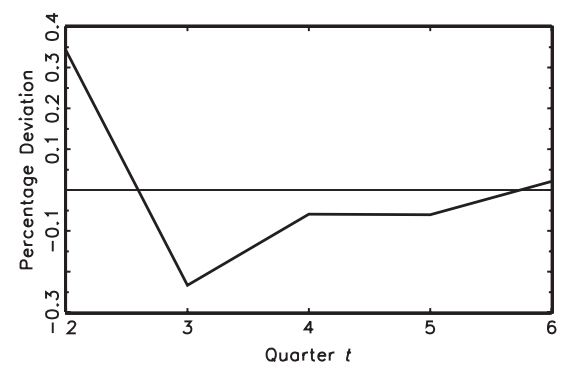

Individual response of hours: $t=3$

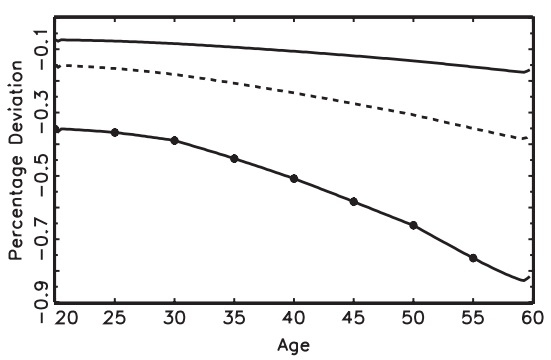

Individual response of hours: $t=2$

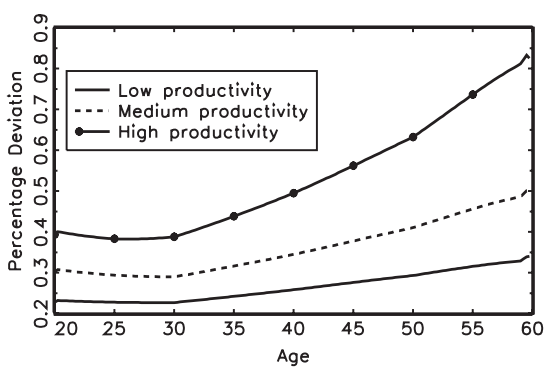

Labor supply elasticity

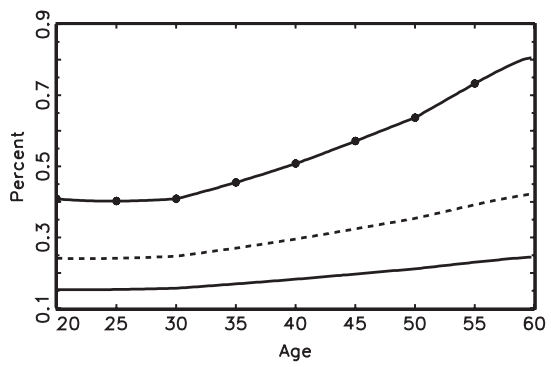

FIGURE 4. Impulse response of working hours to a monetary shock, $n=4, \operatorname{Tr}_{t}=0$.

aggregate profits (not illustrated) and, thus, the market income of the rich agents. And third, the user cost of capital increases on impact. All three effects increase the market income of the older and more productive workers to a larger extent than that of the younger and less productive workers.

Next, consider what happens if prices are sticky (the broken line in Figure 3). Both the wage effect and the effect from the user costs of capital are still operative. What makes the difference, and thus accounts for the more equal distribution of market income in the first period of the shock, is the huge drop in aggregate profits by over $7 \%$. In the first period after the shock, the price adjustment restores profits and real wages decrease, which explains the increase of the Gini coefficient of market income in this period.

In the model with a progressive tax schedule, the monetary shock induces a more unequal distribution of market income in the first period. At first sight, this seems counterintuitive, because the same mechanisms are at work. However, considering the stationary distribution of capital shares and the stationary ageprofile of labor supply resolves the puzzle. First, in the case of a progressive rather than a proportional tax schedule, the high-productivity workers build up less capital relative to the low- and medium-productivity workers, and thus the gap between the individual capital shares narrows. Accordingly, the distribution of income and wealth is more equal in the economy with progressive taxation. For this reason, the drop of aggregate profits has a much smaller negative (in terms of the change of the Gini coefficient) distributional effect on market income. 


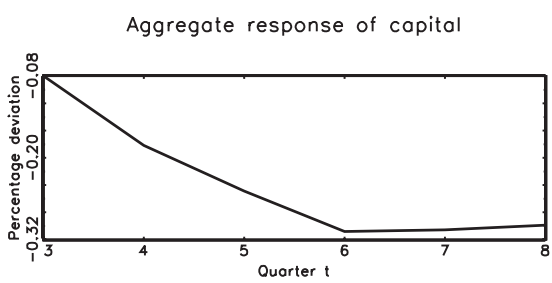

Individual response of capital: $t=4$

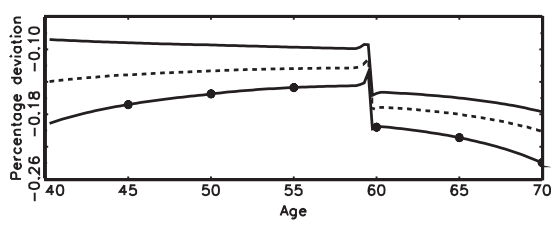

Individual response of capital: $t=6$

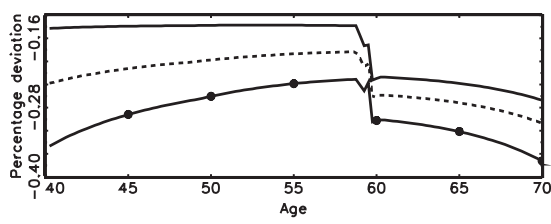

Individual response of capital: $t=3$

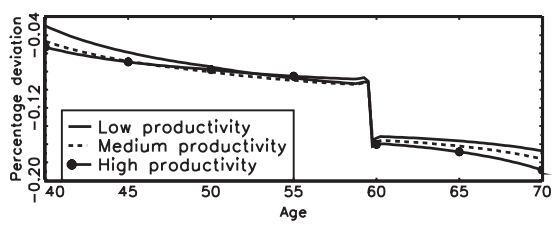

Individual response of capital: $t=5$

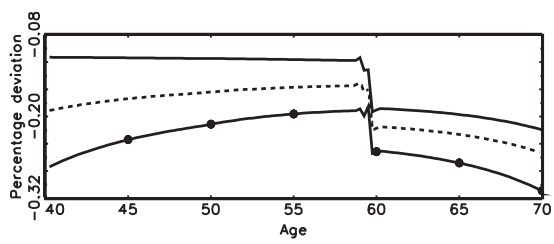

Individual response of capital: $t=7$

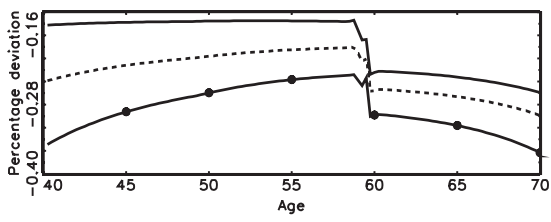

FIGURE 5. Impulse response of capital to a monetary shock, $n=4, \operatorname{Tr}_{t}=0$.

Second, in comparison to the case of the proportional income tax, the labor supply elasticity of the low- and medium-productivity workers at ages 40-60 is higher, so that labor supply reacts more strongly in response to a monetary expansion. As a consequence, the wage increase favors the market income in this age group. The upper right panel of Figure 3 reveals that the progressive tax system reverses the impact of the shock on the distribution of market income. The distribution of disposable income becomes more equal (the solid line with squares).

The imperfect indexation of taxes and pensions reduces the impact effect of the money shock on the distribution of market income (see the solid line with dots in the upper left panel of Figure 3) because the marginal tax rates of the more productive workers increase with inflation. Because the real wage rate drops below its stationary value in the second period, the pattern of labor income change is reversed in the next period, and the distribution of market income becomes more equal. The imperfect indexation of taxes and pensions also strengthens the impact of the money shock on the distribution of disposable income as the real tax burden of richer agents increases and the real value of their pensions declines. The Gini coefficient of disposable income drops by $0.15 \%$ and remains below its stationary value for three more quarters.

The more equal distribution of disposable income translates into a more equal distribution of wealth in the first quarter of the shock $(t=3)$. Yet the savings behavior reverses this effect in the following quarters. In Figure 5, we plot the percentage changes of the capital stock for those aged between 40 and 70, i.e., 
Gini ratio of market income

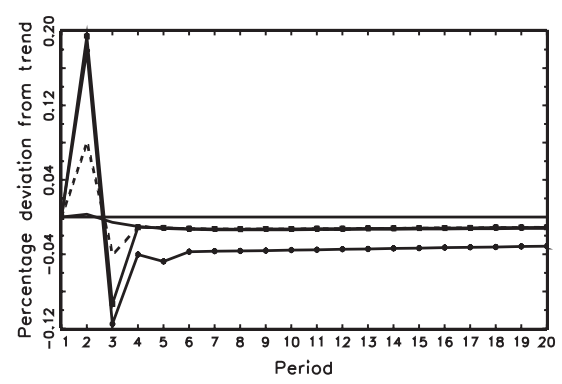

Gini ratio of wealth

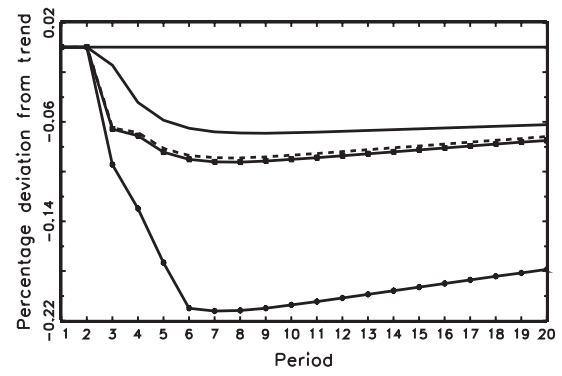

Gini ratio of disposable income

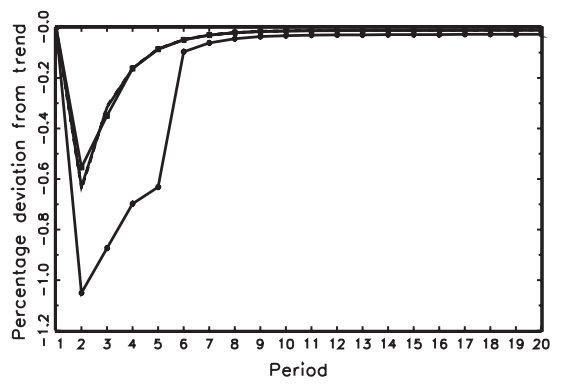

- Proportional tax, without frictions

-.. Proportional tax, sticky prices, no indexation

- Progressive tox, sticky prices, no indexation

- Progressive tox with all frictions

FIGURE 6. Impulse response of capital to a monetary shock, $n=4, G_{t}=0$.

the relatively rich individuals in each productivity group. The upper right panel shows that the relative amount of dissaving increases with productivity and age. This explains the narrowing of the wealth distribution in the first period after the shock. However, starting in the second period after the shock $(t=4)$, we see that the changes in the savings-age profile of the most productive agents are upward-sloping until retirement. Thus, the younger agents reduce their wealth more than the older and richer agents, so that the wealth distribution becomes more unequal.

In the Technical Appendix to this paper, we also consider the case where the government redistributes its additional income from bequests, seignorage, and taxes as a lump sum to the households. Here, we only report the results from this exercise. The impulse responses of the Gini coefficients for market income, disposable income, and wealth are graphed in Figure 6. Evidently, we find much stronger effects in the model without government consumption. An increase of the money growth rate by one standard deviation reduces the Gini coefficient of disposable income in the model with all nominal frictions by $1.05 \%$ in the first period. Half of this drop is explained by the indexation of taxes and pensions. The Gini ratio of wealth displays a U-shaped response with its trough at $0.21 \%$ below the stationary value, occurring five quarters after the shock.

The importance of the tax and transfer system is also highlighted by the cyclical behavior of the income share of the poorest $10 \%$ of the population. As we have explained, if the government spends its extra income solely on consumption, the 
decrease of the Gini ratio of disposable income is mainly driven by the income losses of the richer part of the population. Accordingly, the income share of the first decile drops $1.8 \%$ below its stationary value in the second period of the shock. If, however, the government redistributes its extra income to the households as a lump sum, the Gini ratio of disposable rises and peaks at $5.4 \%$ above its stationary value in the first period before it, thereafter, slowly returns to its stationary value (not illustrated).

\subsection{Inflation and Distribution Dynamics After a Technology Shock}

Figure 7 displays the response of key variables following a technology shock of one standard deviation $(0.7 \%)$ in period 2 . The responses in the OLG model (solid line) are almost identical to those in the corresponding Ramsey model (broken line), with minor difference only between those of consumption, investment, and government spending.

Following an increase in the technology level, the marginal products of capital and labor increase. As a consequence, investment and production rise. The effect of the technology shock on individual labor supply is ambiguous, as illustrated in Figure 8. Younger workers decrease their labor supply in period 2, whereas older workers even supply more hours (the upper right panel). Again, this behavior can be explained by the labor supply elasticity, which is highest for the older and high-productivity workers. In addition, we have a strong wealth effect that results from the increase in total income. ${ }^{13}$ When inflation adjusts and real wages increase even further, all age groups supply more labor.

Figure 9 displays the impulse responses of the Gini ratios of market income, disposable income, and wealth. The three channels identified in the previous paragraph account for the more unequal distribution of market income in response to a technology shock: the richer agents supply relatively more labor, earn more capital income, and receive more dividends. Notice that the tax and pension system is not able to reverse this pattern. In particular, the Gini coefficient of disposable income increases by $0.05 \%$ above its stationary value. Accordingly, the co-movement of inflation and disposable income inequality is the same as in the case of a monetary shock. In response to a positive technology shock, inflation decreases while inequality of disposable income increases. In the case of a positive monetary shock, inflation increases and, again, disposable income inequality moves in the opposite direction, i.e., it decreases.

Even though the distribution of disposable income becomes more unequal after a positive technology shock, the distribution of wealth becomes more equal because (1) low- and medium-productivity workers increase their savings relatively more than high-productivity workers (the substitution effect of higher returns on capital dominates the income effect), (2) the changes in the savings-age profile (not shown) decrease between ages 40 and 55 (due to the wealth effect), and (3) all retired workers reduce their savings markedly. As a consequence, the Gini coefficient of wealth declines by $0.09 \%$ over the next five years (= twenty periods). 

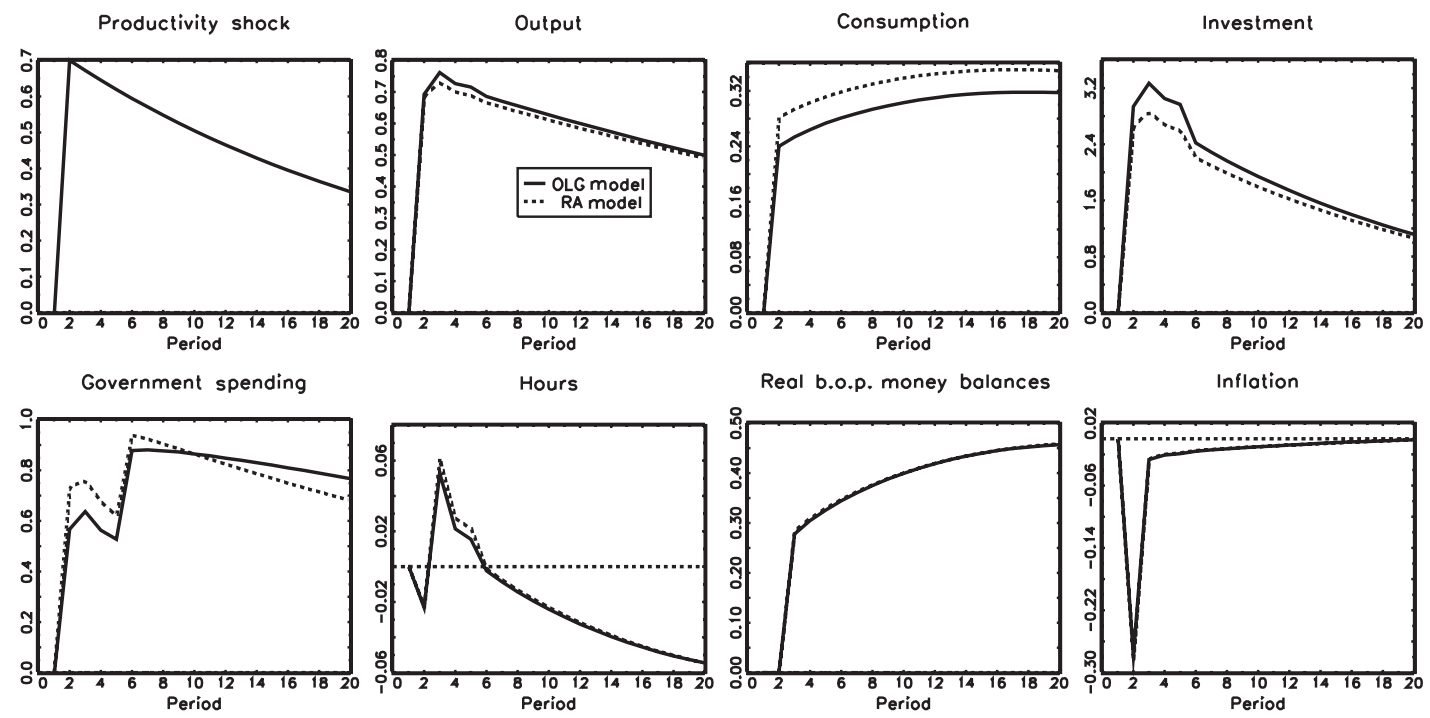

Real b.o.p. money balances

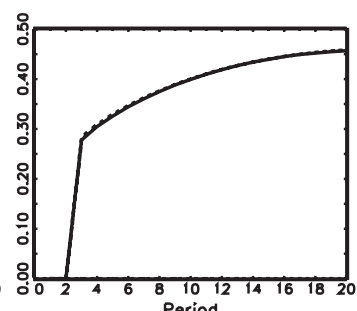

Inflation

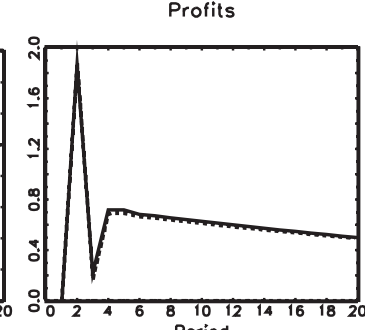

User costs of copitol
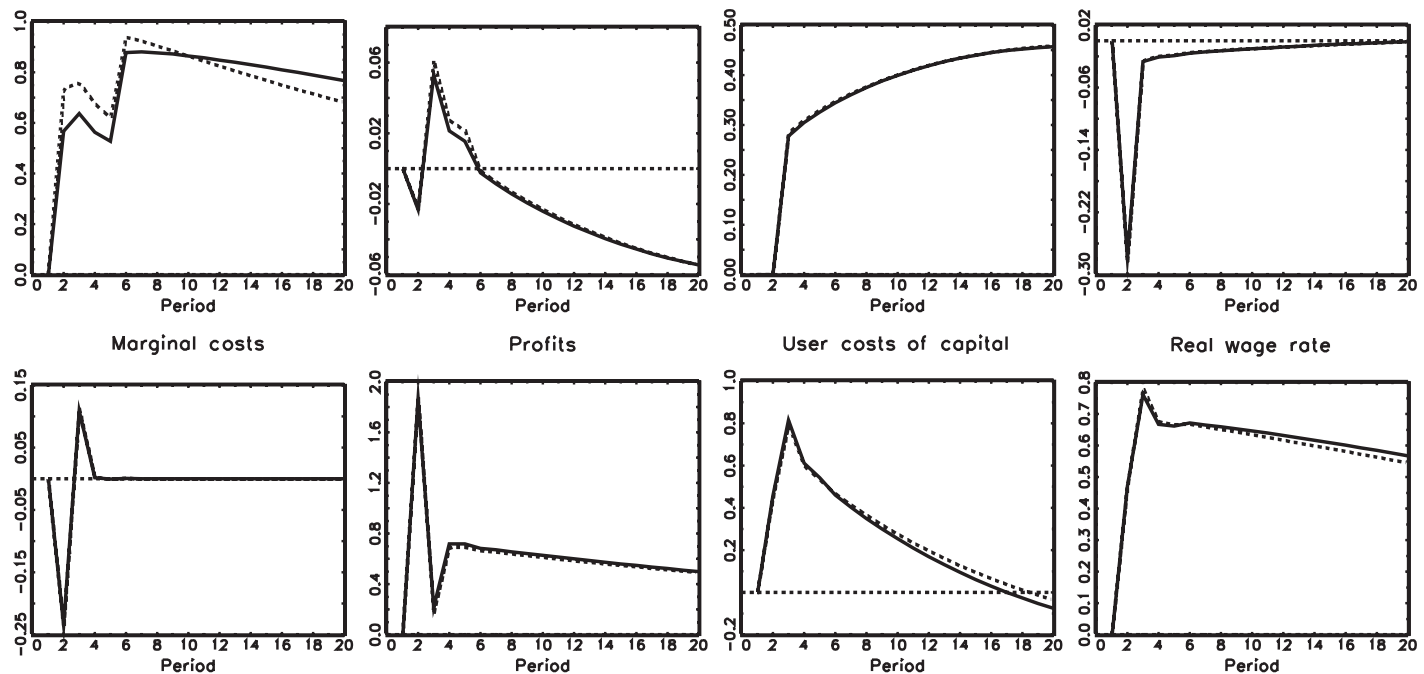

Real woge rate

FIGURE 7. Technology shock in the OLG model, $n=4, \operatorname{Tr}_{t}=0$. 
Aggregate response of hours

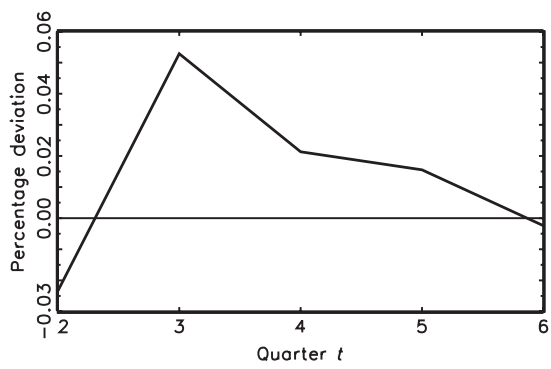

Individual response of hours: $t=3$

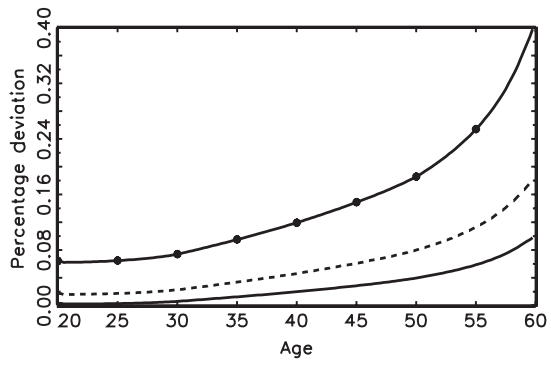

Individual response of hours: $t=2$

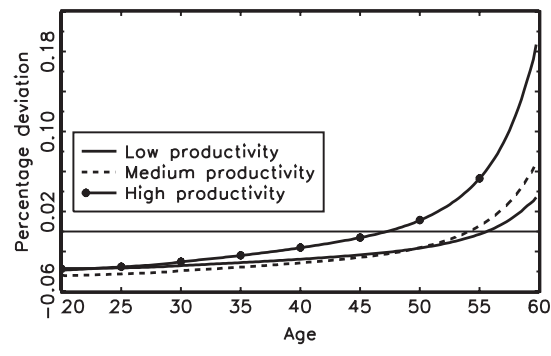

Labor supply elasticity

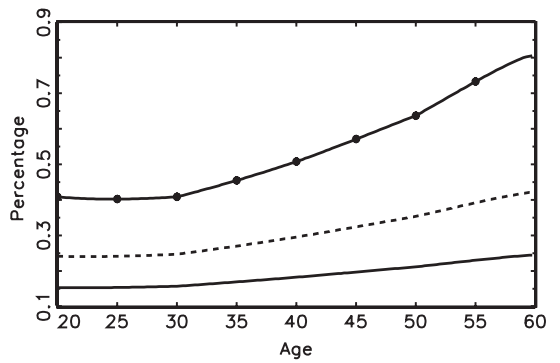

FIGURE 8. Impulse response of working hours to a technology shock, $n=4, \operatorname{Tr}_{t}=0$.

\section{BUSINESS-CYCLE PROPERTIES OF THE OLG MODEL}

In this section, we first compare the behavior of the variables of our OLG model with that of those of the U.S. economy. We will pay special attention to the cyclical behavior of the distribution measures. In the second part, we compare the OLG model with the corresponding representative-agent model.

\subsection{Summary Statistics}

Table 2 presents the second moments of a few key variables for the U.S. economy and compares them to those of the OLG model. The estimates for the U.S. economy are taken from Cooley and Prescott (1995) (for all real variables) and from Cooley and Hansen (1995) and Cooley and Quadrini (1999) (for inflation). Although the volatility of investment relative to output in our model is much larger than that in the data, hours and consumption display too little volatility. In addition, real wages and inflation fluctuate too much in our model. The correlations of the variables with output except for hours and investment are in good accordance with the observations from the US economy.

In Table 3 we present second moments of the Gini ratios of disposable income and wealth. We compare two different economies. The first economy is hit by both technology and monetary shocks, whereas the second economy is driven 
Gini ratio of market income

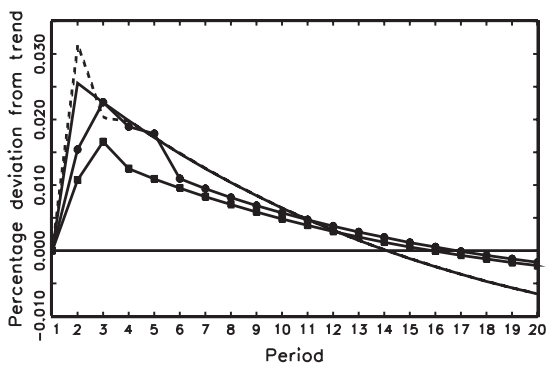

Gini ratio of wealth

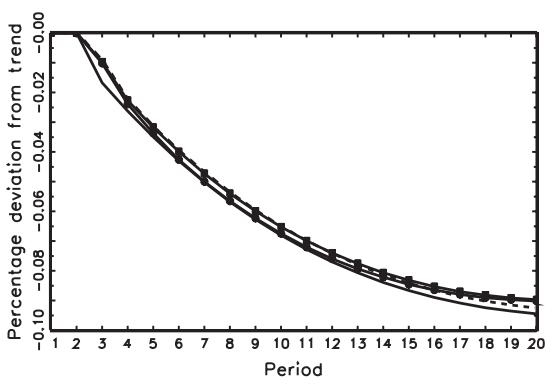

Gini ratio of disposable income

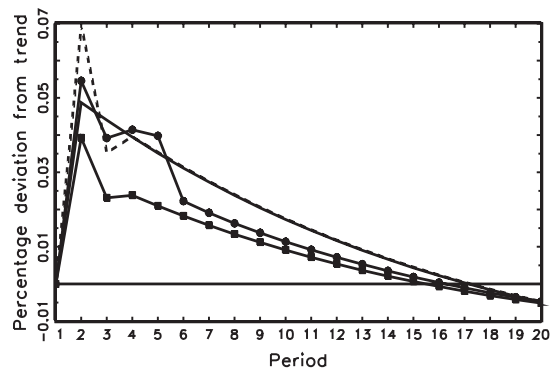

- Proportional tox, without frictions

-.. Proportional tox, sticky prices, no indexation

- Progressive tox, sticky prices, no indexation

- - Progressive tox with oll frictions

FIGURE 9. Distributional effects of a technology shock, $n=4, \operatorname{Tr}_{t}=0$.

by technology shocks only. If the government transfers its excess revenues as a lump sum to the household sector $(\xi=0)$, monetary policy shocks contribute considerably to the volatility of the income distribution. By stabilizing money growth (i.e., by setting $\sigma_{\theta}=0$ ), the standard deviation of the Gini ratio of disposable income drops from 1.39 to 0.15 . In the model where excess revenues

TABLE 2. Second moments: U.S. data vs. the OLG model $(\varphi=0.25$, $\xi=1)$

\begin{tabular}{lccccc}
\hline & \multicolumn{2}{c}{ U.S. data } & & \multicolumn{2}{c}{ OLG model } \\
\cline { 2 - 3 } \cline { 5 - 6 } & $s_{x} / s_{y}$ & $r_{x y}$ & & $s_{x} / s_{y}$ & $r_{x y}$ \\
\hline Output & $s_{y}=1.72$ & 1.00 & & $s_{y}=1.06$ & 1.00 \\
Consumption & 0.74 & 0.83 & & 0.34 & 0.85 \\
Investment & 4.79 & 0.91 & & 7.96 & 0.53 \\
Hours & 0.92 & 0.86 & & 0.40 & 0.49 \\
Real wage & 0.44 & 0.68 & & 1.66 & 0.76 \\
Inflation & 0.35 & 0.34 & & 1.66 & 0.26 \\
\hline
\end{tabular}

Notes: Second moments in the OLG model from HP-filtered simulated time series. The numbers are averages from 100 simulations. The length of each indivdual time series is 150 quarters. $s_{x}=$ standard deviation of variable $x, r_{x y}=$ cross correlation of variable $x$ with output. 
TABLE 3. Cyclical behavior of Gini ratios

\begin{tabular}{lrrrrr}
\hline & \multicolumn{2}{c}{$\begin{array}{c}\text { With monetary } \\
\text { shock }\end{array}$} & & \multicolumn{2}{c}{$\begin{array}{c}\text { Without monetary } \\
\text { shock }\end{array}$} \\
\cline { 2 - 3 } \cline { 5 - 6 } & $\xi=0$ & $\xi=1$ & & $\xi=0$ & $\xi=1$ \\
\hline$s_{y^{d}}$ & 1.39 & 0.21 & & 0.15 & 0.07 \\
$r_{y^{d} y}$ & 0.12 & 0.21 & & 0.64 & 0.90 \\
$s_{w}$ & 0.24 & 0.07 & & 0.06 & 0.05 \\
$r_{w y}$ & 0.08 & -0.14 & & 0.04 & -0.13 \\
\hline
\end{tabular}

Notes: Second moments from HP-filtered simulated time series. The numbers are averages from 100 simulations. The length of each individual time series is 150 quarters. $s_{y} d=$ standard deviation of Gini ratio of disposable income, $r_{y} d_{y}=$ cross-correlation of Gini ratio of disposable income with output, $s_{w}=$ standard deviation of Gini ratio of wealth, $r_{w y}=$ cross correlation of Gini ratio of wealth with output.

are spent on government consumption $(\xi=1)$, this effect is less dramatic but still significant: the standard deviation of the Gini ratio is reduced from 0.21 to 0.07. Also note that without money supply shocks the concentration of the income distribution is procyclical, independent of the share of government consumption $\xi$. In the economy with both monetary and technological disturbances the opposing effects on the distribution of income result in an almost acyclical distribution. The distribution of wealth is unrelated to the business cycle, because the respective correlations coefficients are small in all four economies considered in Table 3.

\subsection{Comparison with the Corresponding Representative-Agent Model}

Table 4 compares the second moments from our OLG model with those from a representative-agent version of this model. It confirms the result from the analysis of the model's impulse responses in Figures 2 and 7 that there are only minor differences between the two models. The most obvious case concerns investment, which is more volatile in the OLG model, and even more so in the case $\xi=1$. In accordance with Rios-Rull (1996), who studies a much simpler nonmonetary OLG model, we find that if one is interested only in the study of the behavior of aggregate variables, the representative-agent model generates almost the same results as the OLG model and, of course, is much easier to compute and, therefore, is the tool of choice.

\section{CONCLUSION}

Our study provides an initial step toward the understanding of the distributional effects of monetary policy over the business cycle. So far, only the long-run distribution effects of monetary policy have been analyzed in computable general equilibrium models, such as Erosa and Ventura (2002), Cysne et al. (2005), or Heer and Süssmuth (2007). The effect of unexpected inflation on the distribution of 
TABLE 4. OLG versus representative-agent (RA) model

\begin{tabular}{|c|c|c|c|c|c|c|}
\hline & \multicolumn{3}{|c|}{ OLG model } & \multicolumn{3}{|c|}{ RA model } \\
\hline & $s_{x}$ & $r_{x y}$ & $r_{x}$ & $s_{x}$ & $r_{x y}$ & $r_{x}$ \\
\hline & \multicolumn{6}{|c|}{$\xi=0$} \\
\hline Output & 0.97 & 1.00 & 0.65 & 0.95 & 1.00 & 0.66 \\
\hline Consumption & 0.39 & 0.94 & 0.73 & 0.42 & 0.95 & 0.72 \\
\hline Investment & 4.35 & 0.99 & 0.58 & 4.07 & 0.99 & 0.60 \\
\hline Hours & 0.40 & 0.28 & -0.20 & 0.42 & 0.31 & -0.18 \\
\hline Real wage & 1.67 & 0.70 & -0.08 & 1.68 & 0.68 & -0.08 \\
\hline \multirow[t]{2}{*}{ Inflation } & 1.61 & 0.11 & -0.04 & 1.61 & 0.10 & -0.04 \\
\hline & \multicolumn{6}{|c|}{$\xi=1$} \\
\hline Output & 1.06 & 1.00 & 0.57 & 0.98 & 1.00 & 0.64 \\
\hline Consumption & 0.36 & 0.85 & 0.75 & 0.39 & 0.92 & 0.74 \\
\hline Investment & 8.46 & 0.53 & 0.71 & 6.88 & 0.52 & 0.69 \\
\hline Hours & 0.43 & 0.49 & -0.32 & 0.45 & 0.39 & -0.26 \\
\hline Real wage & 1.77 & 0.76 & -0.09 & 1.80 & 0.70 & -0.10 \\
\hline Inflation & 1.76 & 0.26 & -0.04 & 1.75 & 0.18 & -0.04 \\
\hline
\end{tabular}

Notes: Second moments from HP-filtered simulated time series. The numbers are averages from 100 simulations. The length of each individual time series is 150 quarters. $s_{x}=$ standard deviation of variable $x, r_{x y}=$ cross correlation of variable $x$ with output, $r_{x}=$ first-order autocorrelation of variable $x$.

income and wealth has not received attention in any dynamic general equilibrium model as yet.

We present a model that replicates the following important channels of the effects of monetary policy on the distribution of income and wealth: (1) the response of prices, and hence the change in the markups, interest rates, wages, and, ultimately the factor incomes of the individuals, (2) the "bracket creep" effect, and (3) inflation-dependent pensions. In our model, an expansionary monetary shock is found to decrease the inequality of both the distribution of factor income and disposable income after the first period of the shock, even though only to a small extent. A much larger effect arises if the government redistributes its additional revenues from seignorage and taxes lump sum to the households: Following a monetary shock of one standard deviation, the Gini ratio of disposable income immediately drops by $1.05 \%$ below its stationary value as compared to only $0.15 \%$ in our benchmark model. Half of this effect is accounted for by the imperfect indexation of tax brackets and pensions for inflation.

Our framework can only be regarded as a first step to a full-fledged analysis of the short-run distribution effects of monetary policy. We emphasize the role of cash holdings and neglect the distribution of nominal asset price positions, and in particular of nominal fixed-income bonds. As described by Doepke and Schneider (2006b, 2006c), young middle-class households are the main beneficiaries of unanticipated inflation, as they are net nominal borrowers due to their mortgage 
debt. Nevertheless, our analysis can serve as a benchmark case for future work that may consider a more sophisticated model with additional assets besides money and capital, namely housing and nominal bonds.

\section{NOTES}

1. When we talk about the poor, we refer to the income-poor if not mentioned otherwise.

2. The Technical Appendix is available upon request from the authors.

3. We follow Castañeda et al. (2003) in our choice of a functional form for the utility from leisure. In particular, this additive functional form implies a relatively low variability of working hours across individuals that is in good accordance with empirical evidence.

4. In the Technical Appendix, we also consider briefly the case of perfect annuity markets. However, in this case the consumption-age profile is upward-sloping and not hump-shaped, as empirically observed. Therefore, we focus on the case of unintended bequests.

5. The details of the pension scheme are explained in Section 3.3.

6. Maußner (2010) provides detailed derivations of the different log-linear Phillips curves encountered in the literature.

7. In the Appendix and in our simulations, we also consider the case of a proportional income tax.

8. See the Technical Appendix for the derivation of this definition.

9. The estimates of the Frisch intertemporal labor supply elasticity $\eta_{n, w}$ implied by microeconometric studies and the implied values of $\gamma$ vary considerably. MaCurdy (1981) and Altonji (1986) both use PSID data to estimate values of 0.23 and 0.28 , respectively, whereas Killingsworth (1983) finds a U.S. labor supply elasticity equal to $\eta_{n, w}=0.4$. Domeij and Floden (2006), however, argue that these estimates are biased downward due to the omission of borrowing constraints.

10. A sensitivity analysis for $m \in\{1,2\}$ is provided in the Technical Appendix.

11. This pattern does not hold in the model with government transfers. For low-productivity workers, these transfers constitute a relatively large part of their disposable income, and, thus, induce a strong negative income effect. As a result, the age-profile of hours worked for this group lies below the profile for the medium-productivity workers (see Figure 6 in the Technical Appendix).

12. This result has already been pointed out in a simpler model of the real economy by Huggett (1996). He finds that we are able to replicate the empirically observable heterogeneity of wealth in a computable general equilibrium model (except for the very rich households) if we introduce both life-cycle savings and individual earnings heterogeneity.

13. The responses of output and employment are consistent with the empirical evidence estimated by Galí (1999) and Francis and Ramey (2005) with a VAR for the U.S. economy. They show that a supply shock increases output but depresses employment in the first few quarters.

\section{REFERENCES}

Altonij, Joseph G. (1986) Intertemporal substitution in labor supply: Evidence from micro data. Journal of Political Economics 94, S17-S215.

Basu, Susanto and John Fernald (1997) Returns to scale in US production: Estimates and implications. Journal of Political Economy 105, 249-283.

Bils, Mark and Peter J. Klenow (2004) Some evidence on the importance of sticky prices. Journal of Political Economy 112, 947-985.

Budría Rodríguez, Santiago, Javier Díaz-Giménez, Vincenzo Quadrini, and José-Víctor RíosRull (2002) Updated facts on the U.S. distributions of earnings, income, and wealth. Federal Reserve Bank of Minneapolis Quarterly Review 26, 2-35.

Bulir, Ales (2001) Income Inequality: Does Inflation Matter ? IMF Staff Papers 48(1).

Calvo, Guillermo A. (1983) Staggered prices in a utility-maximizing framework. Journal of Monetary Economics 12, 383-398. 
Castañeda, Ana, Javier Díaz-Giménez, and José-Víctor Ríos-Rull (2003) Accounting for the US earnings and wealth inequality. Journal of Political Economy 111, 818-857.

Cooley, Thomas F. and Gary D. Hansen (1995) Money and the business cycle. In Thomas F. Cooley (ed.), Frontiers of Business Cycle Research, pp. 175-216. Princeton, NJ: Princeton University Press.

Cooley, Thomas F. and Edward C. Prescott (1995) Economic growth and business cycles. In Thomas F. Cooley (ed.), Frontiers of Business Cycle Research, pp. 1-38. Princeton, NJ: Princeton University Press.

Cooley, Thomas F. and Vincenzo Quadrini (1999) A neoclassical model of the Phillips curve relation. Journal of Monetary Economics 44, 165-193.

Cysne, Rupens P., Wilfredo L. Maldonado, and Paulo K. Monteiro (2005) Inflation and income inequality: A shopping-time approach. Journal of Development Economics 78, 516-528.

Deininger, Klaus and Lyn Squire (1996) A new data set measuring income inequality. World Bank Economic Review 10, 565-591.

Doepke, Matthias and Martin Schneider (2006a) Aggregate implications of wealth redistribution: The case of inflation. Journal of the European Economic Association 4, 493-502.

Doepke, Matthias and Martin Schneider (2006b) Inflation and the redistribution of nominal wealth. Journal of Political Economy 114(6), 1069-1097.

Doepke, Matthias and Martin Schneider (2006c) Inflation as a Redistributive Shock: Effects on Aggregates and Welfare. NBER working paper 12319.

Domeij, David and Martin Floden (2006) The labor supply elasticity and borrowing constraints: Why estimates are biased. Review of Economic Dynamics 9, 242-262.

Easterly, William and Stanly Fischer (2001) Inflation and the poor. Journal of Money, Credit and Banking 33, 160-178.

Erosa, Andres and Gustavo J. Ventura (2002) On inflation as a regressive consumption tax. Journal of Monetary Economics 49, 761-795.

Francis, Neville and Valerie Ramey (2005) Is the technology-driven real business cycle hypothesis dead? Shocks and aggregate fluctuations revisited. Journal of Monetary Economics 52, 1379-1399.

Galí, Jordi (1999) Technology, Employment, and the business cycle: Do technology shocks explain aggregate fluctuations? American Economic Review 89, 249-271.

Galli, Rossana and Rolph van der Hoeven (2001) Is Inflation Bad for Income Inequality: The Importance of the Initial Rate of Inflation. International Labor Organization employment paper 2001/29.

Gouveia, Miguel and Robert O. Strauss (1994) Effective federal individual income tax functions: An exploratory empirical analysis. National Tax Journal 47(2), 317-339.

Hansen, Gary (1993) The cyclical and secular behavior of the labor input: Comparing efficiency units and hours worked. Journal of Applied Econometrics 8, 71-80.

Heer, Burkhard and Bernd Süssmuth (2007) Effects of inflation and wealth distribution: Do stock market participation fees and capital income taxation matter? Journal of Economic Dynamics and Control 31, 277-303.

Huggett, Mark (1996) Wealth distribution in life-cycle economies. Journal of Monetary Economics 17, 953-969.

İmrohoroğlu, Ayse, Selahattin İmrohoroğlu, and Douglas H. Joines (1995) A life cycle analysis of social security. Economic Theory 6, 83-114.

Killingsworth, Mark R. (1983) Labor Supply. Cambridge, UK: Cambridge University Press.

Klenow, Peter J. and Oleksiy Kryvtsov (2008) State-dependent or time-dependent pricing: Does it matter for recent U.S. inflation? Quarterly Journal of Economics 123, 863-904.

Krusell, Per and Anthony A. Smith (1998) Income and wealth heterogeneity in the macroeconomy. Journal of Political Economy 106, 867-896.

MaCurdy, Thomas E. (1981) An empirical model of labor supply in a life-cycle setting. Journal of Political Economy 89, 1059-1085.

Maußner, Alfred (2010) Derivation of New Keynesian Phillips Curves. Mimeo, University of Augsburg.

Meh, A. Césaire, José-Víctor Ríos-Rull, and Yaz Terajima (2008) Aggregate and Welfare Effects of Redistribution of Wealth under Inflation and Price-Level Targeting. Bank of Canada working paper 2008-31. 
Meh, A. Césaire and Yaz Terajima (2008) Inflation, Nominal Portfolios, and Wealth Redistribution in Canada. Bank of Canada working paper 2008-19.

Prescott, Edward (1986) Theory ahead of business cycle measurement. Federal Reserve Bank of Minneapolis Quarterly Review 10, 9-22.

Quadrini, Vincenzo (2000) Entrepreneurship, saving and social mobility. Review of Economic Dynamics 3, 1-40.

Ríos-Rull, José-Víctor (1996) Life-cycle economies and aggregate fluctuations. Review of Economic Studies 63, 465-489.

Romer, Christina D. and David H. Romer (1998) Monetary Policy and the Well-Being of the Poor. NBER Working Paper 6793. 